\section{Hungry for Glory: Team Korea in the World Medical Football Federation Championships}

\author{
Ik Jun Lee \\ Viz Aesthetic Plastic Surgical Clinic, Seoul, Korea \\ Correspondence: Ik Jun Lee \\ Viz Aesthetic Plastic Surgical Clinic, 187 Mullae-ro, Yeongdeungpo-gu, Seoul 150-034, Korea \\ Tel: +82-2-2672-1318, Fax: +82-2-2672-1345, E-mail: leeikjun@naver.com \\ No potential conflict of interest relevant to this article was reported.
}

Received: 5 Aug 2012 • Revised: 6 Aug 2012 • Accepted: 7 Aug 2012

pISSN: 2234-6163 • elSSN: 2234-6171

http://dx.doi.org/10.5999/aps.2013.40.1.82 • Arch Plast Surg 2013;40:82-84

Copyright (C) 2013 The Korean Society of Plastic and Reconstructive Surgeons

This is an Open Access article distributed under the terms of the Creative Commons Attribution

Non-Commercial License (http://creativecommons.org/licenses/by-nc/3.0/) which permits unrestricted non-commercial use, distribution, and reproduction in any medium, provided the original work is properly cited.

Last year, I had the opportunity to compete in the 17th World Medical Football Federation Championships (WMFFC), from July 23 to August 1, in Manchester, England. Korea has participated in the WMFFC since 2006; and in 2009, the games were held in Seoul, the first WMFFC outside of Europe. As a private practice physician, leaving the office for a little more than ten days was no easy task. Over the past two years, however, I had been playing soccer as part of a rehabilitation plan for a knee injury I suffered several years earlier; and the WMFFC came at a perfect time for me in my recovery. So I seized the opportunity and survived the attendant wrangling, planning, re-scheduling, and jetlag that came with it.

My twelve-hour flight brought me to London with two days to explore before the games began. Eager to beat the jetlag and avoid my humid hotel room, I took a tour of the city with my colleagues. In keeping with the overall theme of the trip, the first stop on our tour was Stamford Bridge Stadium, the stomping grounds of the Chelsea Football Club, one of the top performing teams in England's Premier League. Stamford Bridge, opened in 1877, is the 8th largest Premier League stadium and the proud home of the Chelsea FC since their establishment in 1905.

A high-spirited and attractive female tour guide led us on a private tour of the locker rooms, the press conference room, and other notable places at Stamford Bridge. While touring the players' locker room, she quipped about the reasons Drugba and Anelka (two legendary Chelsea strikers) had lockers placed next to one another. But her dry British wit, coupled with her London accent, went completely over my head. I found myself tagging along with a fellow Korean who graciously interpreted decontextualized chunks of her spiel for me. For what it's worth, she mentioned something about the content of Drugba's locker and the size of Lampard's salary; which got a lot of laughs from those who got the joke.
For the last leg of the tour, they had us line up two-by-two and run up the players' tunnel onto the field as pre-recorded audience cheers were piped in through the overhead speakers. I must admit it was exhilarating to run out onto the green the way the players do.

I found myself thinking: 'Wow! World-famous soccer players compete in front of a huge audience in this awesome stadium. It must be heaven for both players and fans!' Suddenly, I was struck by a memory of myself drinking a beer alone while watching a FC Seoul game at the nearly empty Sangam World cup Stadium on a hot summer Wednesday. I'm proud of Korea for playing so well internationally, given the differential support and interest in this sport between nations. After leaving Stamford Bridge, we stopped off at other famous tourist attractions, such as Buckingham Palace, the Tower Bridge, Big Ben, and the House of Parliament, before returning to our hotel rooms.

My family and I departed by train from Euston Station to Manchester on Saturday morning. We got off at Picadilly and headed to the Midland Hotel, located in downtown Manchester. As soon as I had unpacked, I hailed a cab for Old Trafford, the home of Manchester United. Old Trafford is the biggest stadium after Wembley, where England's national football team holds their matches. With a capacity of 76,000, Old Trafford is the biggest Premier League stadium.

As expected, huge numbers of tourists swarmed the stadium, a far cry from the handful we saw at Chelsea. I was glad that I had made reservations for my tour from Korea, so that I could comfortably enjoy the tour of the stadium.

The tour of Old Trafford was similar to that of Chelsea. However, I was excited to find traces of Ji-Sung Park, who plays for Manchester United, all over the stadium. I even had someone snap a photo of me in front Ji-Sung Park's uniform. While there, I made a solemn promise to myself to play hard in the Championships.

On the eve of the matches, all of the teams got together for dinner and entertainment. At my hotel they held the drawing for team heats. Team Korea was in group C with Australia, Spain, and Austria. This meant we didn't need to go up against the top contenders, England and Hungary, in the preliminaries. At this I felt my heart greedily advance its ambition from the modest goal of reaching quarterfinals to the ever-coveted championship.

Because the WMFFC is usually held in Europe, it's difficult for young Korean doctors without an established practice to make the trip. Most years, our team has consisted of soccer fanatic doctors over the age of forty.

In the past, the Korean team has consisted of about 10 players who could not achieve good ratings in the WMFFC because the competition schedules were extremely tough for such a small number of players. Every day for a week, the teams of the 12 participating countries had qualifying rounds in 3 groups (in which the first half and second half were 40 minutes each), and the last 8 teams to survive the contest participated in the final tournament.

This year, however, there were many newer, younger members on the Korean team, which now numbered 25; we all felt that the time 
had come for team Korea to take home the glory. We had our first match, against the Australian team, at 2 o'clock that Sunday.

Sunday morning, after breakfast, I strolled through downtown Manchester with some colleagues, enjoying the relaxed street atmosphere and making use of the electric tram when my feet grew tired. Prior to my arrival, I expected the weather in Manchester to be cloudy and rainy or extremely hot. However, everyday the air was cool and crisp, like a delicious Korean autumn. In contrast, I learned from a phone call back to Korea that while I was away there had been floods in Seoul and landslides near my home!

The setting felt so familiar even though I was far from home; I felt as if I had lived there for a long time, or even that I could live there from that point on. In fact, it felt like Ji-Sung Park himself could have popped out of the locker room, having just finished shaving before a game, ready to greet me, his fellow player, with a grin on his face.

Though some key players who had not yet arrived were conspicuously absent, the excellent fitness of our younger members and our overall high morale led us to expect an easy victory against our opponents from down under.

Nevertheless, our team was totally defeated, with a final score of 1-5. Unfortunately, team Australia was far stronger than we had expected. I also found myself blaming the jetlag and the absence of some of our best players. After closing the first half 1-1, our stamina (much like our chances of victory) dropped precipitously in the second half. Uncowed by this loss, however, we resolved to focus on the next match.

Later that evening, the mayor of Manchester had invited all the teams to City Hall. Entering the hall felt, in my imagination, like being feasted at a medieval castle. The mayor delivered a congratulatory address to us and people chatted over wine, beer, and cocktails. Unfortunately, a feast was not forthcoming. It should have been our first clue that, unlike the Korean tradition of hospitality that provides complementary snacks whenever drinks are served (even, for example, if you order a can of beer at a karaoke bar), no snacks were

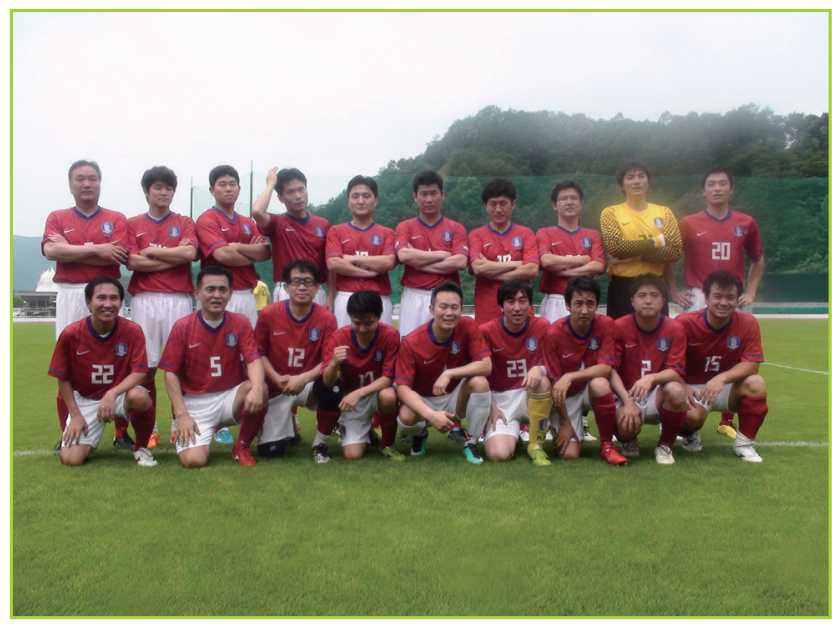

Fig. 1. Before leaving, the kick-off ceremony for the Korean Medical Football Team. provided with the drinks.

From there we moved to a dinner banquet hosted by the British Medical Football Team, who were also this year's Championship host team, at a Chinese restaurant. My teammates and I brought our appetites. I remember thinking to myself as I walked through the doors, "I'm going to eat sweet-and-sour pork, fried chicken with sweet and sour sauce, and pot stickers!" But when we entered the restaurant there was no food to be found. Not only was there no food, the tables and chairs were still neatly stacked against a far wall. I had not eaten anything since the match earlier in the day and my blood sugar was already crashing from the few empty calories I'd taken in beverage form at the mayor's reception. I went back outside to make sure that this was, in fact, the place; the front of the building proudly featured the words "Banquet Hall" in oriental-style lettering.

This was the first time the players had experienced something like this at the Championship, so at first everyone seemed to be waiting around to see what would happen.

Eventually, crestfallen, I made my way back up to the 4th floor of the restaurant to join the 400 or so players and their families from all over the globe. After an hour, the conversations of our cosmopolitan gathering had ground to a trudging murmur, as we watched with hungry eyes and rumbling stomachs the restaurant staff trickle in and begin to set up the tables and chairs around us. It's quite a thing to hear "when will we eat?" in two-dozen languages.

Eventually, the wait staff laid out the buffet tables; there were only four dishes to choose from. Our hunger had gotten the better of us, and we found ourselves complaining about the British Medical Football Team and the mayor of Manchester. "Was this the way of British hospitality?" "Had the economy collapsed at some point?" "Last night's opening events weren't that great either, where they?" But as we dug into the four dishes made available and our blood sugar (and moods) worked their way to less toxic levels, our tempers and our judgment settled down. Still, we unanimously, if not impartially, agreed that the 2009 WMFFC held in Seoul had been much better.

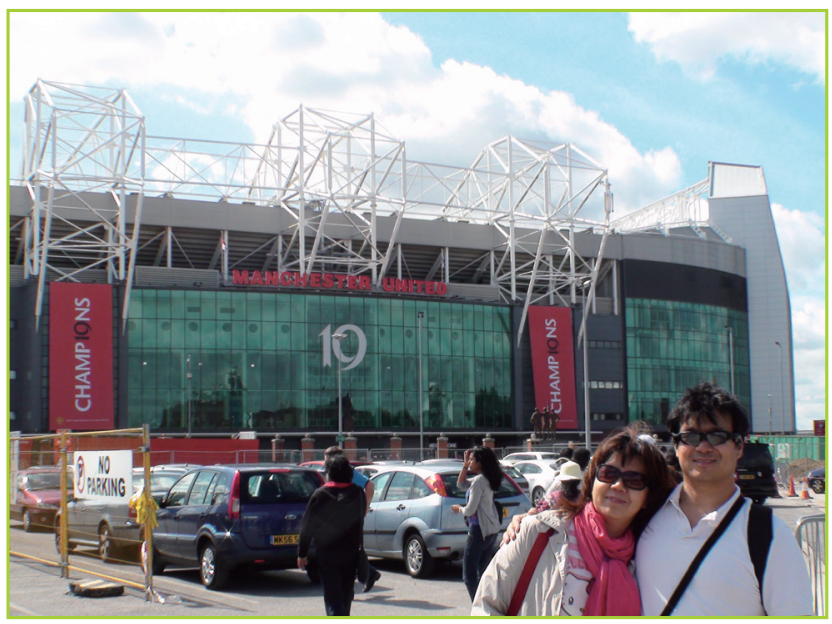

Fig. 2. Old Trafford, home of Manchester United. 


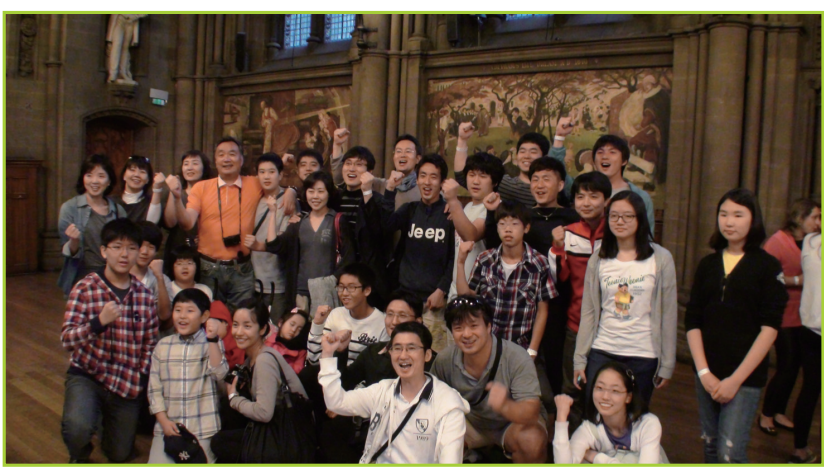

Fig. 3. The mayor of Manchester hosting the welcoming ceremony.

Our next match had us up against Spain, the founders of the WMFFC. My teammates and I were still sore from our last defeat and were looking for a chance to redeem ourselves. Of equal importance was the fact that this game decided who would go on to the quarterfinals.

Though we seemed evenly matched to the Spanish-we were of similar heights and build with comparable skills-we struggled during the first half. Apparently, even the even pot-bellied Spanish players can hustle. Nonetheless, we prevailed with a score of 2-1.

The next day we played the last game of the preliminary round against Austria, who had hosted last year's WMFFC and whom we had gone up against that same year as well. I was heartened by our team's exponential growth since we last faced them-we'd grown from just over 10 players to 25 , nearly double the number of players of the Austrian team.

They were fierce enough, though. We stayed on the defensive for a while, pushed back by their aggressive tactics. We ultimately beat them as well, at 3-0, moving onto the quarterfinals with two wins and one loss. As we ran ourselves into the ground in celebration, wheeling each other around and tossing each other in the air, we felt a joy greater than what we Koreans had experienced at the World Cup semifinals,.

We had achieved our modest goal: to make it to the semifinals. In our own minds we were already victorious.

The day after the prelims, we each took some personal time off to visit more tourist attractions in London, Liverpool, and York. Later that afternoon, there was a medical conference where each of us pre-

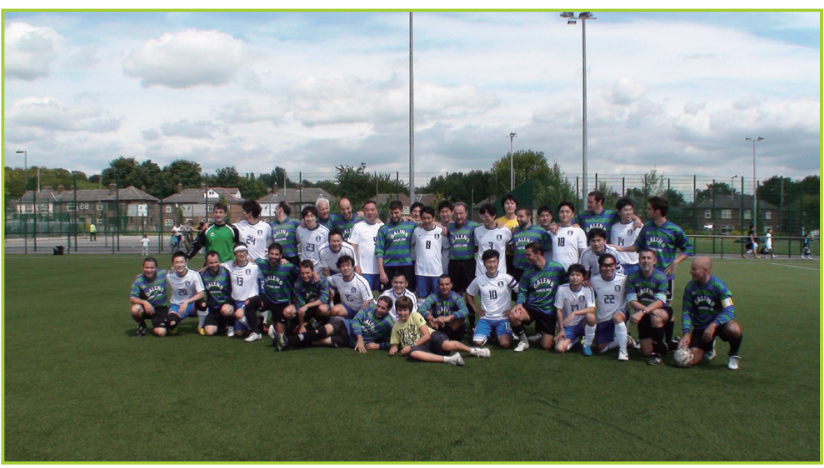

Fig. 4. A photo before the qualifying match against Spain to commemorate our trip.

sented on a topic. The WMFFC is work as well as play, you see.

The outcome of the lottery for the semifinals had us playing another match against Spain, who had brought in two reinforcements to even their odds against us. It felt good to know we commanded their respect, and even a bit of their fear. A few players wore each others' uniforms by accident. I prefer to believer it was out of nervousness.

The game was hard fought, ending in a 1-1 tie. Ultimately, it was a penalty shot that decided who advanced to the semifinals. Wow! Was the spirit of the 2002 Korean-Japan World cup still alive because we Koreans also played a match against Spain in 2002?

We finally won and had the opportunity to advance to the semifinals by a penalty shoot-out! However, sadly, we didn't win the penalty shoot-out and our Spanish counterparts went on to the semifinals. Though Spain beat us by an incredibly narrow margin, they went on to win in the finals against England.

The remaining placement matches didn't hold the same allure for our team. Some of us returned to Korea to attend to our practices while others stayed to play in the remaining matches and tour the country. I was glad we got as far as we did, achieving our initial goal of making the quarterfinals, and that none of my compatriots were injured. We showed our potential out on the green and I look forward to next year.

If there's one thing I regret, though, it's that in all my wandering around the streets of Manchester, before and after the games, I never did manage to bump into Ji-Sung Park. 